\title{
Iceberg calving rates from northern Ellesmere Island ice caps, Canadian Arctic, 1999-2003
}

\author{
Scott WILLIAMSON, ${ }^{1}$ Martin SHARP, ${ }^{1}$ Julian DOWDESWELL, ${ }^{2}$ Toby BENHAM ${ }^{2}$ \\ ${ }^{1}$ Department of Earth and Atmospheric Sciences, University of Alberta, Edmonton, Alberta T6G 2E3, Canada \\ E-mail: martin.sharp@ualberta.ca \\ ${ }^{2}$ Scott Polar Research Institute, University of Cambridge, Lensfield Road, Cambridge CB2 1ER, UK
}

\begin{abstract}
Optical satellite imagery was used to estimate glacier surface velocities and iceberg calving rates from Agassiz and western Grant Ice Caps, Nunavut, Canada, between 1999 and 2003. The largest mean annual surface velocities ranged from $\sim 400$ to $700 \mathrm{~m} \mathrm{a}^{-1}$, but velocities in the $\sim 100-200 \mathrm{~m} \mathrm{a}^{-1}$ range were common. Summer velocities were up to an order of magnitude larger than annually averaged velocities. The highest velocity $\left(\sim 1530 \mathrm{~m} \mathrm{a}^{-1}\right)$ was measured on the floating tongue of Lake Tuborg Glacier between 19 July and 19 August 2001. Calving rates from individual glaciers varied by up to a factor of two between successive years. Summer calving rates were $\sim 2-8$ times larger than annual average rates. The average ratio of the calving flux due to terminus-volume change to that due to ice flow through the glacier terminus was $\sim 0.81$ for the annual rates and $\sim 1.71$ for summer rates. The estimated mean annual calving rate from Agassiz Ice Cap in the period $1999-2002$ was $0.67 \pm 0.15 \mathrm{~km}^{3} \mathrm{a}^{-1}$, of which $\sim 54 \%$ emanated from Eugenie Glacier alone. This total rate is similar to a previously estimated calving rate from Devon Ice Cap.
\end{abstract}

\section{INTRODUCTION}

Contemporary sea-level rise is largely the result of ocean thermal expansion and loss of terrestrial ice to the oceans. Approximately $60 \%$ of global ice loss currently originates from ice caps and glaciers (Meier and others, 2007). Recent increases in the rate of wastage of ice caps and glaciers appear to be linked to rapid thinning and retreat of marineterminating glaciers (Meier and others, 2007). Iceberg calving is typically a significant ablation term in the mass balance of such glaciers and may account for up to $40 \%$ of the mass lost annually from ice caps in Arctic regions (Dowdeswell and others, 2002; Burgess and others, 2005). However, calving rates have often been estimated from measurements that were made over short time intervals and extrapolated over longer time periods on the assumption that ice-flow velocities are constant (e.g. Burgess and others, 2005; Short and Gray, 2005). Annual iceberg calving rates have rarely been measured and there are few studies of the temporal variability in calving rates. Abdalati and others (2004) reported a trend towards low-elevation thinning of glaciers and ice caps in the Canadian Arctic Archipelago, but the role of changing ice dynamics and calving rates in this thinning is not yet understood.

A glacier's velocity, and thus the transfer of mass to lower elevations, may increase as surface meltwater penetrates to the glacier bed in summer and enhances or activates basal sliding (Zwally and others, 2002). The velocities of tidewater glaciers may also be influenced by processes such as the removal of the buttressing effect of a floating glacier tongue (Joughin and others, 2004) or winter sea ice (Luckman and Murray, 2005). Longer periods of warm summer air temperatures may extend the summer sea-ice-free season and make more meltwater available to influence basal sliding. Thus, changes in climate could alter rates of tidewater glacier flow and iceberg calving, but this effect is not usually taken into account in predictions of glacier and ice-sheet contributions to global sea-level change (e.g. Church and others, 2001).
The goal of this study is to determine annual and seasonal rates of iceberg calving from major tidewater valley glaciers draining Agassiz and western Grant Ice Caps on northern Ellesmere Island, Nunavut, Canada. Glacier flow velocities, terminus-area changes and iceberg calving rates were determined using satellite imagery acquired during the period 1999-2003, and glacier thickness measurements from airborne radio-echo sounding acquired in 2000. The sum of the calving-rate estimates for the eight major glaciers draining Agassiz Ice Cap provides an estimate of the calving rate from the whole ice cap. Several small, relatively inactive tidewater glaciers draining the ice cap were not included in this study, but their contribution to calving rates from the ice cap is likely negligible.

\section{STUDY AREA}

Ice caps, ice fields and glaciers cover a large fraction of the Canadian Arctic islands. On Ellesmere Island, glacier ice covers approximately $84000 \mathrm{~km}^{2}$, accounting for about onethird of all terrestrial ice in the Arctic outside Greenland (Dowdeswell and Hagen, 2004). The nine tidewater valley glaciers investigated are located between $\sim 79^{\circ} \mathrm{N}$ and $\sim 81^{\circ} \mathrm{N}$ on Ellesmere Island (Fig. 1). Eight of these glaciers drain from Agassiz Ice Cap (approximately $19500 \mathrm{~km}^{2}$ ), while Otto Glacier drains the west side of western Grant Ice Cap (approximately $2000 \mathrm{~km}^{2}$ ). Several of these glaciers do not have official names registered in the Canadian Geographical Names Database (http://gnss.nrcan.gc.ca/gnss-srt/ searchName.jsp), so unofficial names have been assigned according to related geographical features.

The outlet glaciers considered are up to $70 \mathrm{~km}$ long, generally confined between steep valley walls, and have a maximum ice thickness of 500-800 m (Hattersley-Smith and others, 1969). The interior regions of Agassiz and western Grant Ice Caps are moderately mountainous. Surface elevations reach $2201 \mathrm{~m}$ at the summit of Agassiz Ice Cap $\left(80.17^{\circ} \mathrm{N}, 75.5^{\circ} \mathrm{W}\right)$. The local geology consists primarily of 
Palaeozoic and Mesozoic sedimentary rocks (Trettin, 1989). Climate data from Alert (located on the northeastern tip of Ellesmere Island; $82.51^{\circ} \mathrm{N}, 62.35^{\circ} \mathrm{W}$ ) and Eureka (located on the west coast of Ellesmere Island, $\sim 500 \mathrm{~km}$ south of Alert; $79.98^{\circ} \mathrm{N}, 85.93^{\circ} \mathrm{W}$ ) indicate annual precipitation in the range $100-200 \mathrm{~mm} \mathrm{a}^{-1}$ and a mean annual air temperature that has fluctuated around $-17^{\circ} \mathrm{C}$ over the last several decades. Mean monthly air temperatures typically rise above $0^{\circ} \mathrm{C}$ in July and August at Alert, and in June, July and August at Eureka. The surface mass balance of glaciers in the Canadian Arctic islands has been generally negative over the past 45 years, and has become significantly more negative as summer temperatures have increased since 1987 (Koerner, 2005; Gardner and Sharp, 2007).

There have been a limited number of studies of the dynamics of individual glaciers in the study area (Hattersley-Smith, 1969; Holdsworth, 1977; Short and Gray, 2005). Calving rates have been estimated for four glaciers on Ellesmere Island, including Otto Glacier, and surface velocities during the period 2000-04 were estimated for a further eight glaciers using speckle-tracking techniques (Short and Gray, 2005). These include four glaciers draining Agassiz Ice Cap. Ice thicknesses and the distribution of floating glacier termini in the region were determined from airborne radio-echo sounding surveys in the springs of 1966 (Hattersley-Smith and others, 1969) and 2000. The centreline depth of the Otto Glacier terminus was also measured by airborne radio-echo sounding in May 1995 (P. Gogineni, https://www.cresis.ku.edu/research/data/arctic_data.html (accessed May 2004; cited in Short and Gray, 2005)).

\section{METHODS}

\section{Calculation of iceberg calving rates}

The net calving rate $(C)$ has two components: the flux of ice through a glacier's terminus region (the calving volume, CV) and the volume of ice resulting from advance or retreat of the glacier terminus (the terminus-volume change, $\pm \Delta T V$ ). Estimation of the net calving rate requires knowledge of the cross-sectional area of the glacier at the terminus $(K)$, the mean ice displacement through the cross-section $(D)$, and the change in glacier surface area over a period of time $(\Delta \mathrm{TA})$.

The terminus cross-sectional area of each glacier was estimated by modelling the glacier bed as a parabola (after Nye, 1965). The glacier cross-sectional area $(K)$ is represented as a segment of a circle of radius $r$ and central angle $\theta$, which are calculated from the glacier surface width $(c)$ and centre-line depth $(h)$ :

$$
\begin{aligned}
& r=\frac{c^{2}+4 h^{2}}{8 h} \\
& \theta=2 \arcsin \left(\frac{c}{2 r}\right) \\
& K=\frac{r^{2}(\theta-\sin \theta)}{2} .
\end{aligned}
$$

A parabolic width-averaged thickness (Table 1) was determined for each glacier by dividing the segment area $K$ by the surface width $c$.

Upper and lower bounds of the calving rate $\left(C_{\max }\right.$ and $C_{\text {min }}$ ) were estimated using Equations (4-9), where 'image separation' is the time in years between the dates of acquisition of image pairs used to determine ice surface velocities and changes in the surface area of the terminus:

$$
\begin{aligned}
& C_{\text {max }}=\frac{\mathrm{CV}_{\text {max }} \pm \Delta T V_{\text {max }}}{\text { Image Separation }} \\
& C_{\text {min }}=\frac{\mathrm{CV}_{\text {min }} \pm \Delta \mathrm{TV}_{\text {min }}}{\text { Image Separation }}
\end{aligned}
$$

where

$$
\mathrm{CV}_{\max }=\left(D_{\text {surface }}+D_{\text {error }}\right)\left(T+T_{\text {error }}\right) C
$$

and

$$
\mathrm{CV}_{\text {min }}=\left(D_{\text {depth ave }}-D_{\text {error }}\right)\left(T-T_{\text {error }}\right) C
$$

and

and

$$
\Delta \mathrm{TV}_{\max }=\left(\Delta \mathrm{TA}+\mathrm{TA}_{\text {error }}\right)\left(T+T_{\text {error }}\right)
$$

$$
\Delta \mathrm{TV}_{\min }=\left(\Delta \mathrm{TA}-\mathrm{TA}_{\text {error }}\right)\left(T-T_{\text {error }}\right) .
$$

The calving volume $\left(\mathrm{km}^{3}\right)$ is obtained by multiplying the displacement $(\mathrm{km})$ resulting from flow by the width-averaged thickness $(T(\mathrm{~km}))$ and the terminus width $(c(\mathrm{~km}))$. The terminus-volume change $\left(\mathrm{km}^{3}\right)$ is the product of the terminus-area change $\left(\mathrm{km}^{2}\right)$ and width-averaged terminus thickness $(\mathrm{km})$. A terminus retreat is considered a positive contribution to the calving rate, and an advance is a negative contribution. The errors in measurements of glacier surface displacement $\left(D_{\text {error }}\right)$, ice thickness $\left(T_{\text {error }}\right)$ and terminus-area change $\left(\Delta \mathrm{TA}_{\text {error }}\right)$ are incorporated into the calving-rate estimates through the addition of error in Equations (6) and (8) and the subtraction of error in Equations (7) and (9).

The displacement required for these calculations is the average displacement throughout the glacier cross-section, but what is usually measured is the surface displacement near the glacier centre line. In these calculations we assume that there is minimal variation in surface displacement across the glacier, which is probably a reasonable assumption as the fast-flowing outlet glaciers studied here typically have narrow marginal shear zones. Calculation of the depth-averaged displacement requires knowledge of the relative contributions of basal motion and ice deformation to the surface displacement for each glacier studied, which is usually not available. We therefore assign upper and lower estimates to the displacement by assuming (1) that ice flow is due entirely to deformation of glacier ice, in which case the depth-averaged displacement would be $\sim 80 \%$ of the surface value (Paterson, 1994, p. 252), and (2) that flow is entirely due to basal motion, in which case the surface and depth-averaged displacements are the same. Where the glacier terminus is floating, the vertical gradient in displacement will be negligible (Sanderson and Doake, 1979), making the upper estimate of calving rate likely closer to the actual value in these cases. The same is probably true for fast-flowing outlet glaciers that flow primarily by basal sliding or deformation of subglacial sediments, so it is likely that $C_{\max }$ provides a better estimate of $C$ than does $C_{\min }$.

No bathymetric data are available for areas down-fjord of the calving termini studied, so the volume changes associated with terminus advance or retreat were calculated using the measured ice thickness at the glacier terminus. The terminus-area changes observed between 1999 and 2003 result from small $(<\sim 0.7 \mathrm{~km})$ changes in terminus position and likely do not correspond to significant changes in fjord bottom elevation. The changes in glacier thickness 


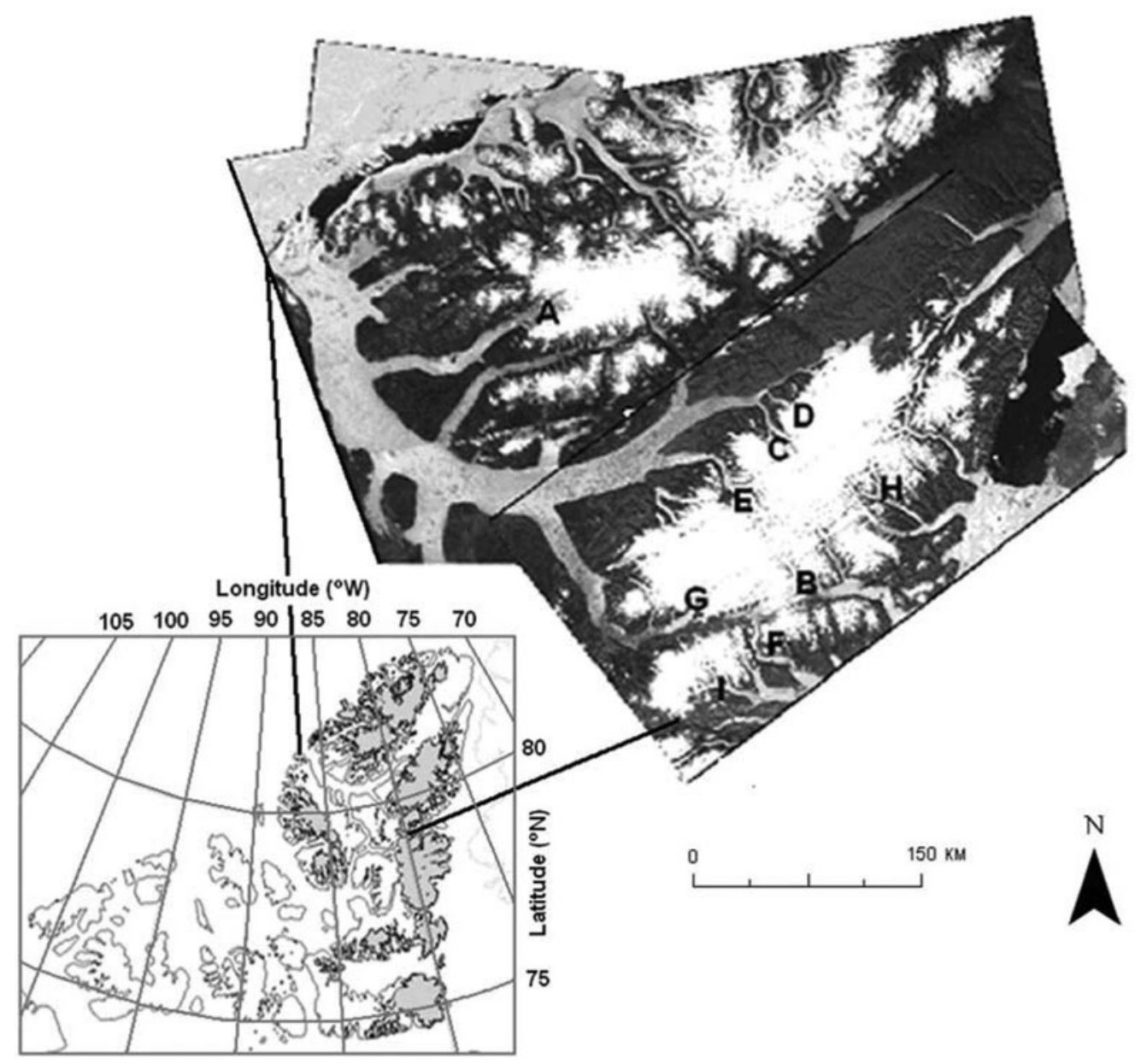

Fig. 1. Tidewater glaciers investigated in this study: A. Otto; B. Eugenie; C. Antoinette; D. Lake Tuborg*; E. d'Iberville; F. Parrish; G. Cañon; H. John Richardson Bay (East)*; I. Sawyer Bay*. (*Indicates unofficial glacier name.) The glacier locations are displayed on 10 July 1999 Landsat 7 panchromatic imagery.

associated with changes in terminus position are therefore assumed to be insignificant, but remain an unquantified source of error in the calving-flux estimates presented here.

\section{Imagery and digital elevation data}

The optical imagery used in this study includes Landsat 7 Enhanced Thematic Mapper Plus (ETM+) panchromatic mode imagery acquired in 1999, 2001 and 2002, and Advanced Spaceborne Thermal Emission and Reflectance Radiometer (ASTER) visible/near-infrared (VNIR) bands 1, 2 and 3 imagery acquired in 2000, 2001, 2002 and 2003. The digital elevation model (DEM) used was subsetted from the Canadian Digital Elevation Dataset (CDED), which was produced from National Topographic System (NTS) $1: 250000$ map sheets derived from 1959/60 aerial photographs. The subsetted DEM was re-projected from the World Geodetic System 1984 (WGS84) geographic coordinate system to a $100 \mathrm{~m}$ resolution North American Datum 1983 (NAD83) Universal Transverse Mercator (UTM) grid system. The DEM has a vertical accuracy of $\pm 20 \mathrm{~m}$ at ice-cap margins and over exposed bedrock (personal communication from A. Gagné, 2002, cited in Burgess and Sharp, 2004).

\section{Image preparation}

1999 Landsat 7 panchromatic scenes covering Agassiz and western Grant Ice Caps were ortho-rectified using the $1: 250000$ NTS maps as geo-reference and the subsetted
CDED DEM to correct for terrain distortion. All orthorectifications were performed using $\mathrm{PCl}$ Geomatica version 8.2 OrthoEngine software. All images used in this study were projected to UTM zone 17, NAD83. Ground-control points (GCPs) were used to link the image being rectified to the subsetted DEM and the NTS map sheets using identifiable landforms. Approximately $40 \mathrm{GCPs}$ were used to orthorectify the three 1999 Landsat 7 images to the NTS map sheets. The associated root-mean-square (rms) errors were no more than 3 pixels, with no single GCP having an error in excess of 4 pixels. Identifying suitable landforms on both the NTS map sheets and the Landsat 7 imagery was difficult, which made it impractical to ortho-rectify additional imagery using the NTS map sheets as the base. All ASTER images and post-1999 Landsat 7 panchromatic images were therefore ortho-rectified using the 1999 Landsat 7 imagery as base and the subsetted DEM as elevation reference using 15 GCPs.

The accuracy of glacier surface displacements derived from repeat images is directly related to the precision of rectification between images. Moreover, estimation of calving rates also requires precise rectification to minimize the error associated with measurements of terminus-area changes. A second rectification process was therefore applied to the previously rectified post-1999 satellite imagery to enhance the precision of rectification and increase the accuracy of glacier surface displacement determination. The ortho-rectified ASTER and Landsat 7 images covering 


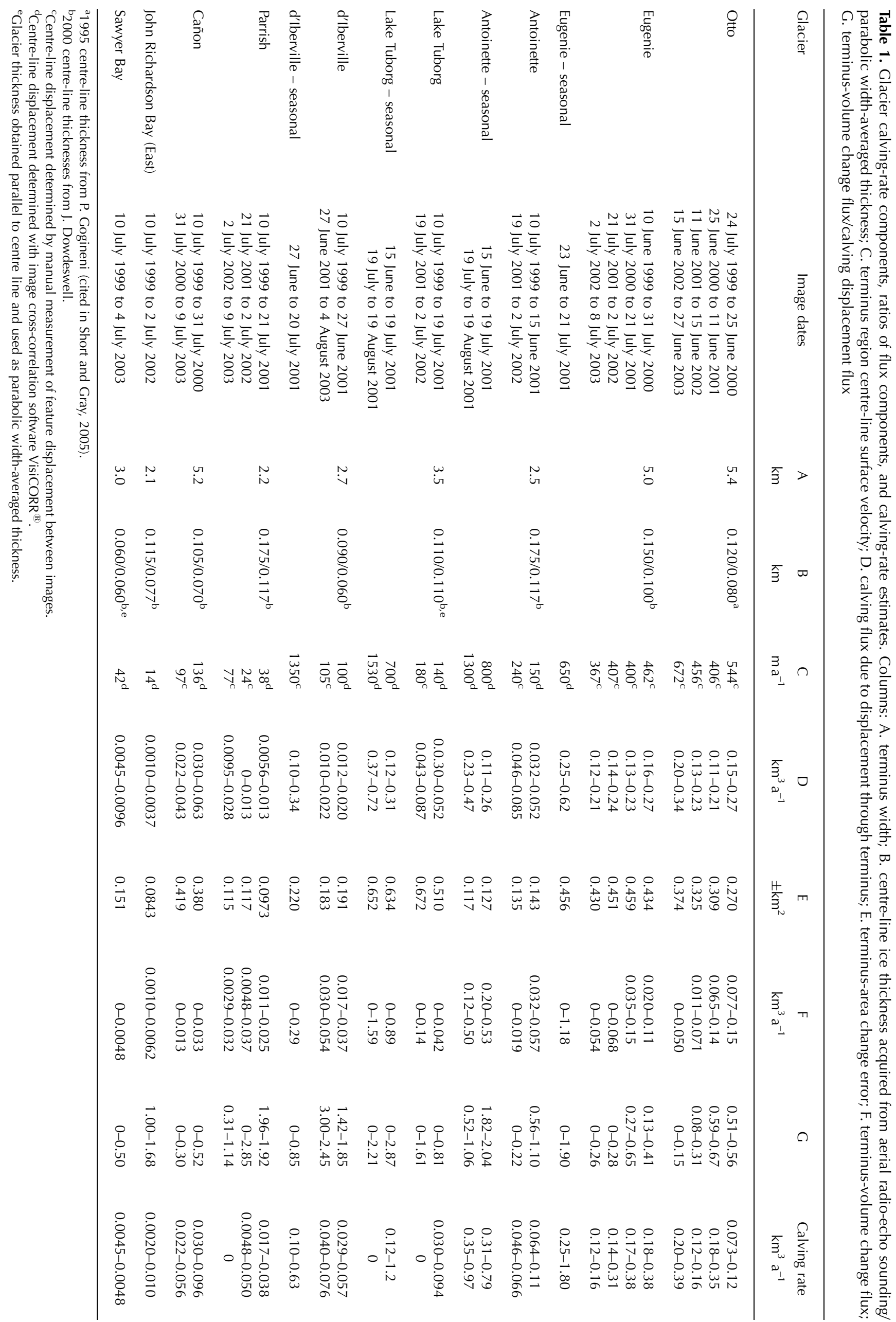




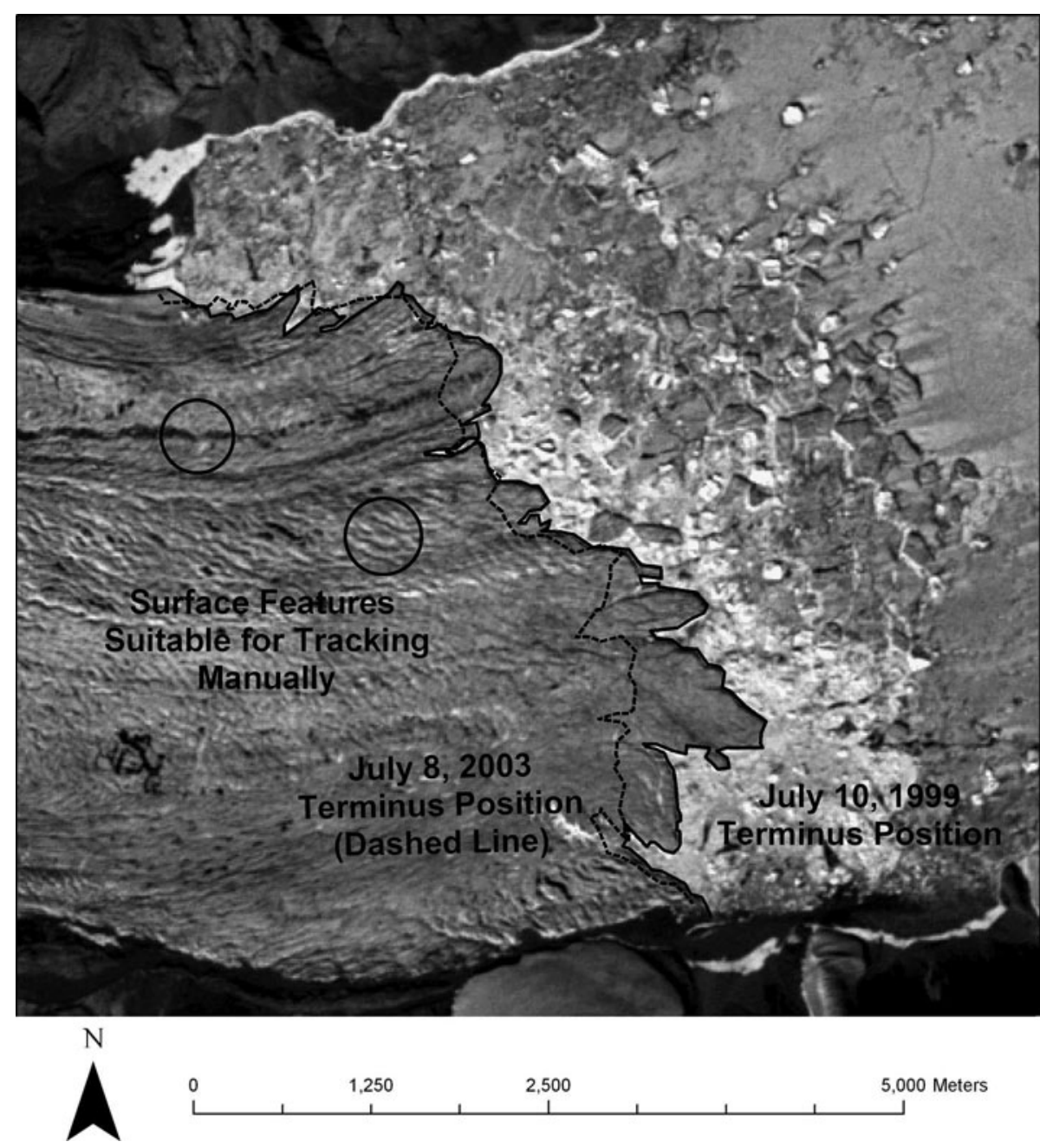

Fig. 2. Selected terminus positions and examples of surface features used to determine surface displacement of Eugenie Glacier displayed on a 10 July 1999 Landsat 7 panchromatic image.

areas extending approximately $10 \mathrm{~km}$ up-glacier and downfjord from calving tidewater glacier termini were subsetted for this second stage of rectification. A third-order polynomial geometric model rectification was applied to the subsetted images using the base Landsat 7 imagery as the reference. The third-order polynomial and geometric rectifications were performed using ERDAS Imagine version 8.6. The purpose of rectifying these smaller regions of interest was to decrease the rectification error for the subsets relative to the rectification error for a whole Landsat 7 or ASTER scene. A polynomial rectification was used because the areas being rectified were relatively small, with limited elevation variation.

Following the second phase of rectification, the rms rectification error within the images was reduced from approximately 3 pixels to 1 pixel, or $15 \mathrm{~m}$, by using $\sim 12$ GCPs (at least 10 GCPs are required to solve a thirdorder polynomial model). The error associated with comparing satellite image pairs that do not include the 1999 base imagery is estimated to be no more than $\pm 30 \mathrm{~m}$. However, for this maximum error to occur, the imagery would have to be offset in opposite directions by the maximum coregistration error. Since the errors are likely random, we argue that an error of $\pm 15 \mathrm{~m}$ better reflects the true error associated with satellite image comparisons. The error associated with digitization of surface features and the glacier terminus is estimated to be \pm 1 pixel, which is $\pm 15 \mathrm{~m}$ for the Landsat 7 and ASTER imagery.

\section{Glacier surface displacement}

Glacier surface displacements were determined either using VisiCORR $^{\circledR}$, a Windows ${ }^{\mathrm{TM}}$ version of the image crosscorrelation software IMCORR (Scambos and others, 1992; Dowdeswell and Benham, 2003), or by manually measuring the displacement between a visually identifiable group of surface features that occur on successive images (Table 1; Fig. 2). The average velocity over the period between images is determined by dividing the displacement by the time between image acquisitions.

Image preparation for image cross-correlation involves several steps. A requirement for image cross-correlation using VisiCORR ${ }^{\circledR}$ is that images are in an eight-bit greyscale tagged image file format (TIFF). The Landsat 7 ETM+ panchromatic images are delivered in this format and do not require further processing. To produce comparable images from ASTER data, bands 1-3 were radiometrically merged to produce an eight-bit greyscale image with digital number values for each pixel equal to the mean of the three separate bands. A high-pass filter was applied to the greyscale images to remove brightness variations related to large-scale topographic features (Scambos and others, 1992). Experiments to determine the optimal kernel size 

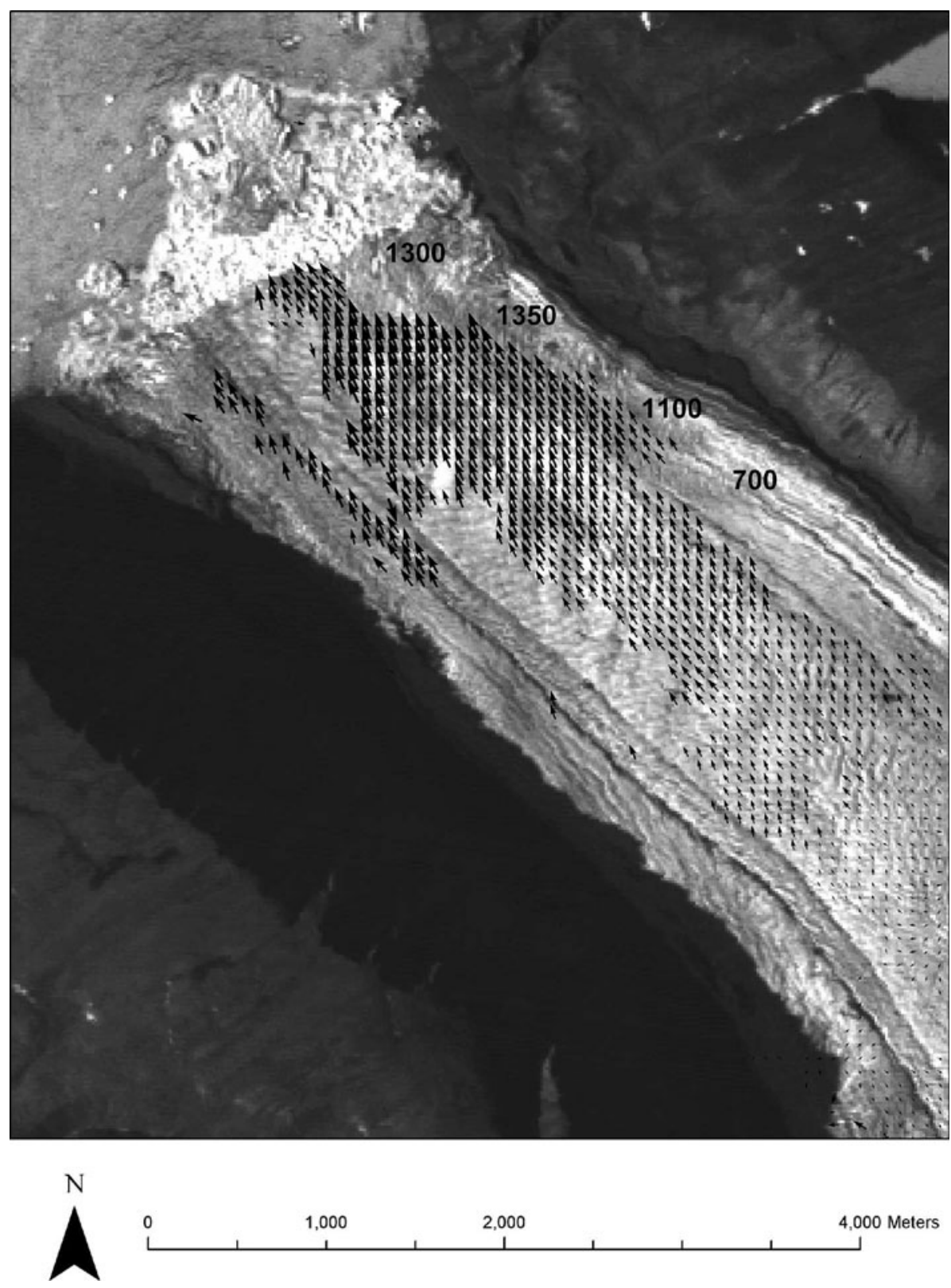

Fig. 3. Image cross-correlation displacement results (m) for Antoinette Glacier between 19 July and 19 August 2001, displayed on greyscale ASTER imagery from 19 July 2001. Approximate annual centre-line velocities $\left(\mathrm{m} \mathrm{a}^{-1}\right)$ are indicated at $1 \mathrm{~km}$ intervals. These velocities are averages of about six adjacent vectors.

for the filter were conducted using filter sizes of up to $7 \times 7$ pixels. A $3 \times 3$ pixel filter size produced images that resulted in the fewest spurious correlations (e.g. adjacent correlations with radically different sign or intensity) and was therefore applied to all images prior to analysis with VisiCORR ${ }^{\circledR}$.

Figure 3 shows $\mathrm{VisiCORR}^{\mathbb{R}}$ results from Antoinette Glacier obtained from an ASTER image pair captured on 19 July and 19 August 2001. The image cross-correlation method measures displacements of small rectangular image areas (chips) rather than of individual pixels and thus produces sub-pixel accuracy in displacement determination (Scambos and others, 1992). The actual velocity for each individual vector can be derived from the resulting map in ESRI's ArcGIS 8.3 software package, producing velocity maps with centre-line velocity and terminus velocity plotted at $1 \mathrm{~km}$ intervals (e.g. Fig. 3). The velocities plotted are the average value of about six velocities derived from adjacent surrounding chips. The error assumed for the displacements used to compute the velocities is $\pm 15 \mathrm{~m}$, which is likely a conservative estimate.

Not all image pairs produced such good results as those shown in Figure 3. Several reasons for this have been suggested: reflectance changes between images related to the time of day at which the images were captured; the absence of surface features that the cross-correlation algorithm can track; and large velocity gradients at the scale of the features that are being searched for (Scambos and others, 1992). In this study, we found that VisiCORR ${ }^{\circledR}$ often produced inconsistent velocity fields when surface displacements between images exceeded $\sim 370 \mathrm{~m}$, but inconsistencies could also occur when displacements were less than this. Vector results were rejected as inconsistent if the majority of the vector orientations were not physically realistic or vectors indicating anomalous flow directions were found across the whole extent of a map. 
Manual measurement of surface feature displacements was used to estimate the centre-line displacement in the terminal region of glaciers for which VisiCORR ${ }^{\circledR}$ did not produce satisfactory results (Fig. 2; Table 1). The manual approach has been shown to be effective for the determination of glacier velocity (e.g. MacDonald and others, 1989), but the results for relatively slow-flowing glaciers with no visually identifiable surface features contain a larger error than those from image cross-correlation, due to the difficulty in consistently identifying specific surface features (Scambos and others, 1992). The error associated with manually measured glacier displacements is a function of feature digitization error and co-registration error, which is $\pm 22 \mathrm{~m}$. When circumstances allowed displacement determination by both the manual and image cross-correlation techniques, the results agreed to within error.

\section{Cross-sectional area of the glacier terminus}

As outlined above, the cross-sectional area of the glacier terminus was determined from measurements of the terminus width and the ice thickness at the glacier centre line and converted to a parabolic width-averaged thickness. Ice thicknesses in the terminal regions of outlet glaciers were measured using $100 \mathrm{MHz}$ airborne radio-echo sounding (RES). The thicknesses of Lake Tuborg and Sawyer Bay Glaciers were directly equated to the parabolic thickness because the RES point measurements were collected parallel to the glacier's centre line. The influence of the error associated with the measurement of glacier width on estimates of calving rates is considered to be insignificant, but an error of $\pm 30 \mathrm{~m}$ (one $15 \mathrm{~m}$ pixel on the lateral margins) was chosen to account for the uncertainty in identifying the lateral margins of the glaciers. The error associated with the estimates of ice thickness derived from radio-echo sounding is assumed to be $\pm 10 \mathrm{~m}$ (Dowdeswell and others, 2004).

\section{Terminus-area changes}

Glacier terminus positions were digitized from the orthorectified imagery at a scale of $\sim 1: 24000$. All vector files were created and analyzed using the ESRI ArcGIS 8.3 software package. Terminus-area change, terminus-area change error and terminus-volume change range are presented in Table 1. Glacier terminus-area changes were measured for restricted areas lying down-glacier from a straight line drawn perpendicular to the direction of glacier flow at a point located further up-glacier than the most up-glacier terminus position recorded during the period covered by the available imagery (Fig. 2). The glacier terminus region, delimited by the imposed up-glacier limit and the terminus in each image, was digitized and converted to a polygon. The area of each polygon was then calculated using a Visual Basic script. Terminus-area change was determined as the change in area of terminus-area polygons between successive images. The error in measured terminus-area change results from the coregistration error and the error involved in digitizing the terminus polygons that define the terminus-area change on post-1999 images multiplied by the composite perimeter length of the area change. The error in 1999 terminus position is taken to be a function of the accuracy of terminus identification only. Identifying terminus-area change was the largest source of error in the calculation of calving rate. This error was sometimes as large as terminus-area change itself. By contrast, the measurement error in glacier depth or displacement was rarely greater than $\sim 10 \%$.

\section{RESULTS}

The glaciers included in the present study can be grouped into three categories, on the basis of their annually averaged velocities: (1) glaciers that have relatively high annual mean flow rates $\left(\sim 500-700 \mathrm{~m} \mathrm{a}^{-1}\right.$; Eugenie and Otto Glaciers); (2) glaciers with moderate annual mean flow rates $(\sim 100-$ $200 \mathrm{~m} \mathrm{a}^{-1}$; Lake Tuborg, Antoinette, d'Iberville and Cañon Fjord glaciers); and (iii) glaciers with relatively low annual flow rates ( 20-80 $\mathrm{m} \mathrm{a}^{-1}$; Parrish, John Richardson Bay and Sawyer Bay glaciers) (Table 1). Radio-echo soundings, with relatively strong bed reflections typical of an ice-water inferface, indicate that Otto (Hattersley-Smith and others, 1969), Eugenie, Lake Tuborg, d'Iberville and Cañon glaciers may have floating termini, whereas Parrish, John Richardson Bay and Sawyer Bay are probably grounded at their termini. It is not clear whether the terminus of Antoinette Glacier is floating or grounded, but the high flow rate at the terminus suggests that it may be approaching flotation. This suggestion is consistent with the observation that all the other glaciers with annual flow rates more than $\sim 100 \mathrm{ma}^{-1}$ appear to have floating termini.

The interannual variability in mean annual velocity is significant for several glaciers (Otto, Eugenie, Cañon and Parrish) and reaches a factor of three for Parrish Glacier. Repeat imagery available for four of the glaciers in 2001 allows an assessment of the magnitude of seasonal velocity variations. The largest summer velocities were measured for Lake Tuborg and Antoinette Glaciers in the period JulyAugust 2001, and for d'Iberville Glacier in the period JuneJuly 2001. These summer velocities $\left(>1 \mathrm{~km} \mathrm{a}^{-1}\right)$ are an order of magnitude larger than the annually averaged velocities $\left(100-200 \mathrm{~m} \mathrm{a}^{-1}\right)$ of these glaciers. At Lake Tuborg and Antoinette Glaciers, the early-summer (June-July) velocities were intermediate between the annual mean and latesummer velocities, suggesting a progressive acceleration of glacier flow during the summer. By comparison, the flow rate of Eugenie Glacier during the early summer $\left(\sim 650 \mathrm{~m} \mathrm{a}^{-1}\right)$ was $\sim 60 \%$ higher than the annual average rate $\left(380-480 \mathrm{~m} \mathrm{a}^{-1}\right)$. Imagery of $\mathrm{d}^{\prime}$ Iberville and Eugenie Glaciers was not available for August 2001, so the late-summer velocity of these glaciers could not be determined. The seasonal velocity variation of the other glaciers could not be determined because repeat summer imagery was not available.

The two most significant iceberg calving sources identified are Otto and Eugenie Glaciers (Table 1), which (at the annual timescale) are the fastest-flowing glaciers analyzed here. The highest single-year calving rate calculated was for Otto Glacier between 2002 and $2003\left(0.39 \mathrm{~km}^{3} \mathrm{a}^{-1}\right)$. The mean calving rate from Otto Glacier between 1999 and 2003 was $0.26 \pm 0.13 \mathrm{~km}^{3} \mathrm{a}^{-1}(1 \mathrm{std} \mathrm{dev}$ ), and that from Eugenie Glacier was $0.31 \pm 0.10 \mathrm{~km}^{3} \mathrm{a}^{-1}$. These two glaciers also show the largest interannual variability in calving rates (up to a factor of 2.9). Fast-flowing glaciers that display significant increases in surface velocity during the summer also display large (up to eight times) seasonal variations in calving rate (Eugenie, Antoinette, Lake Tuborg and d'Iberville glaciers). The average calving rate from the four previously mentioned glaciers was $1.1 \pm 0.50 \mathrm{~km}^{3} \mathrm{a}^{-1}$ in June-July 2001. The average ratio of the calving rate due to terminus-volume change and the rate due to ice flow through the glacier terminus is $\sim 0.81$ for the annual rate and $\sim 1.71$ for summer rates (Table 1 ). 
The best estimate of the iceberg calving rate from Agassiz Ice Cap between 1999 and 2002 is $0.67 \pm 0.15 \mathrm{~km}^{3} \mathrm{a}^{-1}$ (rms of the first standard deviations). Eugenie Glacier alone appears to account for $\sim 54 \%$ of this rate (Table 1 ). The four glaciers with annual mean velocities in the 100$200 \mathrm{~m} \mathrm{a}^{-1}$ range account for $\sim 43 \%$. The three glaciers with annual mean velocities less than $100 \mathrm{~m} \mathrm{a}^{-1}$ account for the remaining $\sim 3 \%$, the majority of which originates from Parrish Glacier.

\section{Comparison with other recent measurements}

The glacier velocities and calving rates reported here were compared to those measured by Short and Gray (2005) for Otto, Cañon and d'Iberville glaciers. Surface velocities only were compared for Lake Tuborg and Antoinette Glaciers. Short and Gray (2005) determined ice surface velocities by applying the speckle-tracking technique to RADARSAT-1 data obtained with a 24 day repeat in either NovemberDecember or February-March during the period 2000-04.

The annual mean surface velocities reported here for Otto Glacier (400-680 $\mathrm{m} \mathrm{a}^{-1}$ ) and Lake Tuborg Glacier (150$200 \mathrm{~m} \mathrm{a}^{-1}$ ) overlap those reported by Short and Gray (2005) for the lower $5 \mathrm{~km}$ of these glaciers for 24 day periods in winter (500-900 $\mathrm{m} \mathrm{a}^{-1}$ for Otto Glacier and 120-230 $\mathrm{m} \mathrm{a}^{-1}$ for Lake Tuborg Glacier). By contrast, our estimates for Antoinette, d'Iberville and Cañon Glaciers (180-220 $\mathrm{m} \mathrm{a}^{-1}$, $\sim 100 \mathrm{~m} \mathrm{a}^{-1}$ and $95-140 \mathrm{~m} \mathrm{a}^{-1}$ respectively) all lie above the range measured by Short and Gray (2005) for the same glaciers. This can likely be explained by the fact that we observed large summer increases in the velocity of Antoinette and d'lberville Glaciers which would tend to make the annual mean velocity of these glaciers higher than the winter values measured by Short and Gray (2005). Unfortunately, we do not have the necessary data to determine the summer velocity of Cañon Glacier, so we cannot tell whether the same explanation applies to that glacier.

Short and Gray's (2005) estimates of the winter calving rate of Otto Glacier are $0.12 \pm 0.03 \mathrm{~km}^{3} \mathrm{a}^{-1}$ for 2002, and $0.37 \pm 0.09 \mathrm{~km}^{3} \mathrm{a}^{-1}$ for 2003 . These values are similar to the calving rates calculated here (Table 1$)$. The similarity in calving rates needs to be explored, however, because the rates are calculated differently. Short and Gray (2005) assumed a uniform ice thickness across the glacier terminus, which would result in higher values than are reported in this study, where the glacier bed was assumed to be parabolic in form. Short and Gray (2005) assigned an error of $\sim 25 \%$ to their estimates of the calving rate on the assumption that they might have overestimated the width-averaged glacier depth by as much as $20 \%$. Although our estimates of the surface velocity of Otto Glacier overlap those of Short and Gray (2005), they do tend to be $\sim 20-30 \%$ lower than those of Short and Gray (2005). This discrepancy is likely related to the difference in techniques used to determine surface displacement. The 1999-2003 velocities used in our calculations are average velocities for the region between $\sim 5 \mathrm{~km}$ and $\sim 2 \mathrm{~km}$ from the terminus, whereas the velocities used by Short and Gray (2005) relate to the terminus itself. The centre-line velocity profiles derived by Short and Gray (2005, fig. 3 ) show a velocity increase of up to $30 \%$ over the terminal $5 \mathrm{~km}$ of the glacier. This would largely explain the difference in the velocities reported in the two studies, and might suggest that we have underestimated the calving rate from Otto Glacier. Finally, Short and Gray (2005) reported a $0.15 \mathrm{~km}^{3} \mathrm{a}^{-1}$ advance of Otto Glacier in 2002 and no change in 2003 . We found a $0.071 \mathrm{~km}^{3} \mathrm{a}^{-1}$ increase in terminus volume between 2001 and 2002, and a $0.050 \mathrm{~km}^{3} \mathrm{a}^{-1}$ decrease between 2002 and 2003. These differences are likely due to the length of the periods covered by the optical and synthetic aperture radar (SAR) imagery. The optical imagery used here provides a better estimate of the true annual rate of terminus-volume change and terminus displacement than the RADARSAT-1 imagery used by Short and Gray.

\section{DISCUSSION}

Before the advent of satellite remote sensing, measurements of glacier velocities in the Canadian Arctic were confined to studies using stake networks on smaller glaciers and on safely accessible outlet glaciers. These studies typically measured annual surface velocities in the $10-50 \mathrm{~m} \mathrm{a}^{-1}$ range (e.g. Koerner, 2002; Copland and others, 2003b). Recent results from satellite remote sensing (Burgess and others, 2005; Short and Gray, 2005; this study) clearly show that large tidewater glaciers in the Canadian Arctic may have surface velocities of up to many hundreds of metres per year.

Surging glacier flow has been of special interest to researchers because of the high velocities that are achieved and the potential for producing large calving rates. Annually averaged velocities of $250-1000 \mathrm{ma}^{-1}$ (e.g. Holdsworth, 1977; Copland and others, 2003a) have been recorded for several probable surging glaciers in the Canadian Arctic. The highest recorded velocity $\left(\sim 2800 \mathrm{~m} \mathrm{a}^{-1}\right)$ was measured at Otto Glacier in the summer of 1959 (Hattersley-Smith, 1969). The impact of glacier surges on calving rates cannot at this point be quantified, but is likely to be substantial at individual glaciers. Even small year-to-year changes in the number of actively surging glaciers may result in large changes in iceberg production from the Canadian Arctic as a whole. In Svalbard, a surge of the $1250 \mathrm{~km}^{2}$ Hinlopenbreen calved about $2 \mathrm{~km}^{3}$ of icebergs in a single year during the active phase of the surge cycle (Liestøl, 1973).

Several studies have indicated that velocities of landterminating glaciers in the Canadian Arctic increase during the summer (e.g. Iken, 1972; Bingham and others, 2003), with peak summer velocities reaching as much as $400 \%$ above winter velocities (Copland and others, 2003b). To date, however, there have been few studies of the seasonal velocity variability of large, fast-flowing tidewater glaciers in the region. Holdsworth (1977) showed that the 1975 summer (July-August) velocity of d'Iberville Glacier, which may have been experiencing a surge at the time, was $~ 9 \%$ higher than the annual average velocity for 1974-75. Moreover the 1974-75 annual average velocity $\left(\sim 457 \mathrm{~m} \mathrm{a}^{-1}\right)$ indicates that the winter velocity at that time was much larger than the velocities reported here and by Short and Gray (2005).

Four of the tidewater glaciers draining Agassiz Ice Cap (Eugenie, Lake Tuborg, Antoinette and d'Iberville) undergo large velocity increases during the summer. The causes of these seasonal velocity increases cannot be determined from the data currently available but could include enhanced basal lubrication or weakening of subglacial sediments due to penetration of surface meltwater to the glacier bed in summer (Zwally and others, 2002), or a reduction in the back pressure exerted on a glacier by sea ice or a floating glacier tongue (Reeh and others, 2001; Joughin and others, 2004). We note that, of the glaciers studied here, those with the largest annual and seasonal velocities are heavily crevassed 
and show abundant evidence of ponding of surface meltwater within crevasse fields, while the more slowly flowing glaciers are drained by large meltwater streams which flow off the terminus and sides of the glaciers. This is at least consistent with the suggestion that the penetration of surface meltwater to the glacier bed may be a contributory factor to the seasonal acceleration of glacier flow.

It has been argued that the stability of glaciers with floating tongues in Greenland is dependent on the back pressure provided by sea ice in front of the glacier, and that calving is limited to the period of seasonal sea-ice retreat and break-up of the shore-fast ice in fjords (Reeh and others, 2001). At Antoinette and Lake Tuborg Glaciers, sea-ice cover was present in June and July 2001, but had completely disappeared by August, when the largest seasonal velocities were recorded. At d'Iberville Glacier, however, a large velocity increase occurred between June and July 2001, when sea-ice cover was still present in the fjord. Thus it would seem that the reduction in the buttressing effect provided by the removal of sea ice is not a necessary condition for the order-of-magnitude summer velocity increase over the annually averaged velocities. It is possible, however, that weakening of the sea-ice cover prior to its removal could facilitate the seasonal increase in ice-flow rates. Furthermore, the increase of the fraction of calving rate attributed to terminus-area change vs displacement flux during the summer indicates that terminus-area change is a more important contributor to calving rate in summer than during winter. This behaviour is potentially the result of thinner or non-existent summer sea ice.

For a tidewater glacier with a floating tongue (Jakobshavn Isbræ, Greenland), Joughin and others (2004) argued that speed-up of the glacier after 1997 was associated with 'back-stress' reductions resulting from disintegration of the floating tongue. For the glaciers in this study, however, only minor changes in terminus area occurred between 1999 and 2003, and the terminus-area changes of the fastest-flowing glaciers (Otto and Eugenie Glaciers) do not appear to be simply correlated with velocity changes. Thus it appears unlikely that the break-up of floating tongues is a factor in the variability of surface velocities and calving rates reported here.

Two previous studies of iceberg calving rates from ice masses in the Canadian Arctic (Burgess and others, 2005; Short and Gray, 2005) were based upon analyses of image pairs captured over periods of $<1$ month during winter, and they assumed that the ice surface velocities measured approximated the long-term average. In light of the significant short-term variability in velocities and calving rates found here, this approach likely underestimates the calving rates.

There have been a number of recent studies of calving rates from Arctic ice masses outside Greenland. Dowdeswell and others (2002) estimated a rate of $0.65 \mathrm{~km}^{3} \mathrm{a}^{-1}$ from the $5500 \mathrm{~km}^{2}$ Akademii Nauk ice cap, Severnaya Zemlya. Here we estimate a calving rate of $0.67 \mathrm{~km}^{3} \mathrm{a}^{-1}$ for Agassiz Ice Cap. Burgess and others (2005) estimated a calving rate of $0.53 \mathrm{~km}^{3} \mathrm{a}^{-1}$ for Devon Ice Cap $\left(\sim 14000 \mathrm{~km}^{2}\right)$. Additional estimates for the Canadian High Arctic are our estimate of $0.26 \mathrm{~km}^{3} \mathrm{a}^{-1}$ (1999-2003) for Otto Glacier/western Grant Ice Cap and $2.81 \mathrm{~km}^{3} \mathrm{a}^{-1}$ for three glaciers draining the Prince of Wales Icefield, Ellesmere Island (Trinity, Wykeham and Ekblaw Glaciers (Short and Gray, 2005)). Finally, Hagen and others (2003) estimated a total rate of $\sim 4 \mathrm{~km}^{3} \mathrm{a}^{-1}$ from the whole of the Svalbard archipelago, of which about $2.5 \mathrm{~km}^{3} \mathrm{a}^{-1}$ comes from the $8100 \mathrm{~km}^{2}$ Austfonna ice cap. This gives a total rate of almost $9 \mathrm{~km}^{3} \mathrm{a}^{-1}$ from these sources. Calving rates from Franz Josef Land, Novaya Zemlya, Axel Heiberg Island, and Manson, Sydkap and Northern Ellesmere Island ice caps have yet to be determined, as have rates from some potentially significant glaciers draining the Prince of Wales Icefield, Ellesmere Island.

By comparison, Dyurgerov and Meier (2005) estimate that the average annual surface mass balance of glaciers in Severnaya Zemlya, Svalbard, Devon Island and Ellesmere Island for the period $1961-2003$ was about $-14 \mathrm{~km}^{3} \mathrm{a}^{-1}$. The addition of the surface mass balance (negative) and mass loss from iceberg calving indicates iceberg calving would account for approximately $40 \%$ of the total annual mass loss from these areas in which there is $\sim 152000 \mathrm{~km}^{2}$ of glacier ice, representing about $60 \%$ of the total ice cover of the Canadian Arctic, Svalbard and the Russian Arctic. Having no estimates of calving fluxes from significant parts of the Ellesmere Island ice fields, the total calving flux from Ellesmere Island is undoubtedly underestimated, as is the fractional contribution of iceberg calving to glacier mass loss from Severnaya Zemlya, Svalbard, Devon Island and Ellesmere Island.

\section{CONCLUSIONS}

Iceberg calving rates were calculated for the major tidewater glaciers draining Agassiz Ice Cap using estimates of surface velocity and terminus-position change derived from repeat optical imagery captured between 1999 and 2003. The average calving rate from Agassiz Ice Cap from 1999 to 2002 was $0.67 \pm 0.15 \mathrm{~km}^{3} \mathrm{a}^{-1}$, with $\sim 54 \%$ of the calving occurring from Eugenie Glacier. The average calving rate from Otto Glacier from 1999 to 2003 was $\sim 0.26 \mathrm{~km}^{3} \mathrm{a}^{-1}$, which is likely the majority of the mass loss by iceberg calving from western Grant Ice Cap. The 1999-2003 annual calving rates are quite variable, with up to three-fold changes occurring between successive years, and two- to eight-fold changes occurring between summer and winter. Summer velocity increases of up to about ten times the annual values have been recorded for July-August, with approximately three-fold increases being common from June to July. The average ratio of the calving rate due to terminusvolume change to that due to ice flow through the glacier terminus is $\sim 0.81$ for the annual rate and $\sim 1.71$ for summer rates. The causes of these seasonal changes cannot yet be discerned with certainty, but surface meltwater penetration and the reduction or removal of the buttressing effect of sea ice may both be involved.

\section{ACKNOWLEDGEMENTS}

This research was funded by grants to $M$. Sharp from the Meteorological Service of Canada (CRYSYS program) and the Natural Sciences and Engineering Research Council, Canada. Radio-echo sounding surveys in 2000 were funded by a grant from the UK Natural Environment Research Council to J. Dowdeswell. P. Gogineni (Radar Systems and Remote Sensing Laboratory, University of Kansas) graciously made available 1995 measurements of the thickness of Otto Glacier. We thank B. Goodison (Environment Canada) for his encouragement of this work. 


\section{REFERENCES}

Abdalati, W. and 9 others. 2004. Elevation changes of ice caps in the Canadian Arctic Archipelago. J. Geophys. Res., 109(F4), F04007. (10.1029/2003JF000045.)

Bingham, R.G., P.W. Nienow and M.J. Sharp. 2003. Intra-annual and intra-seasonal flow dynamics of a High Arctic polythermal valley glacier. Ann. Glaciol., 37, 181-188.

Burgess, D.O. and M.J. Sharp. 2004. Recent changes in areal extent of the Devon ice cap, Nunavut, Canada. Arct. Antarct. Alp. Res., 36(2), 261-271.

Burgess, D.O., M.J. Sharp, D.W.F. Mair, J.A. Dowdeswell and T.J. Benham. 2005. Flow dynamics and iceberg calving rates of the Devon Ice Cap, Nuvavut, Canada. J. Glaciol., 51(173), 219-230.

Church, J.A. and 7 others. 2001. Changes in sea level. In Houghton, J.T. and 7 others, eds. Climate change 2001: the scientific basis. Contribution of Working Group I to the third assessment report of the Intergovernmental Panel on Climate Change. Cambridge, etc., Cambridge University Press, 639-693.

Copland, L., M.J. Sharp and J.A. Dowdeswell. 2003a. The distribution and flow characteristics of surge-type glaciers in the Canadian High Arctic. Ann. Glaciol., 36, 73-81.

Copland, L., M.J. Sharp and P.W. Nienow. 2003b. Links between short-term velocity variations and the subglacial hydrology of a predominantly cold polythermal glacier. J. Glaciol., 49(166), 337-348.

Dowdeswell, J.A. and T.J. Benham. 2003. A surge of Perseibreen, Svalbard, examined using aerial photography and ASTER highresolution satellite imagery. Polar Res., 22(2), 373-383.

Dowdeswell, J.A. and J.O. Hagen. 2004. Arctic glaciers and ice caps. In Bamber, J.L. and A.J. Payne, eds. Mass balance of the cryosphere. Cambridge, etc., Cambridge University Press, 527-557.

Dowdeswell, J.A. and 10 others. 2002. Form and flow of the Academy of Sciences ice cap, Severnaya Zemlya, Russian High Arctic. J. Geophys. Res., 107(B4), 2076. (10.1029/ 2000JB000129.)

Dowdeswell, J.A., T.J. Benham, M.R. Gorman, D. Burgess and M. Sharp. 2004. Form and flow of the Devon Island ice cap, Canadian Arctic. J. Geophys. Res., 109(F2), F02002. (10.1029/ 2003JF000095.)

Dyurgerov, M.B. and M.F. Meier. 2005. Glaciers and the changing Earth system: a 2004 snapshot. Boulder, CO, University of Colorado. Institute of Arctic and Alpine Research. (INSTAAR Occasional Paper 58.)

Gardner, A.S. and M. Sharp. 2007. Influence of the Arctic Circumpolar Vortex on the mass balance of Canadian High Arctic glaciers. J. Climate, 20(18), 4586-4598.

Hagen, J.O., K. Melvold, F. Pinglot and J.A. Dowdeswell. 2003. On the net mass balance of the glaciers and ice caps in Svalbard, Norwegian Arctic. Arct. Antarct. Alp. Res., 35(2), 264-270.
Hattersley-Smith, G. 1969. Recent observations on the surging Otto Glacier, Ellesmere Island. Can. J. Earth Sci., 6(4), Part 2, 883-889.

Hattersley-Smith, G., A. Fuzesy and S. Evans. 1969. Glacier depths in northern Ellesmere Island: airborne radio echo sounding in 1966. Ottawa, Ont., Department of National Defence. Defence Research Board.

Holdsworth, G. 1977. Ice flow and related measurements of d'Iberville Glacier, Ellesmere Island, N.W.T., Canada. Ottawa, Ont., Environment Canada. Inland Waters Directorate. Glaciology Division.

Iken, A. 1972. Measurements of water pressure in moulins as part of a movement study of the White Glacier, Axel Heiberg Island, Northwest Territories, Canada. J. Glaciol., 11(61), 53-58.

Joughin, I., W. Abdalati and M.A. Fahnestock. 2004. Large fluctuations in speed of Jakobshavn Isbræ, Greenland. Nature, 432(7017), 608-610.

Koerner, R.M. 2002. Glaciers of the High Arctic islands. In Williams, R.S., Jr and J.G. Ferrigno, eds. Satellite image atlas of glaciers of the world. US Geol. Surv. Prof. Pap. 1386-J, J129-J134.

Koerner, R.M. 2005. Mass balance of glaciers in the Queen Elizabeth Islands, Nunavut, Canada. Ann. Glaciol., 42, 417-423.

Liestøl, O. 1973. Glaciological work in 1971. Nor. Polarinst. Årb. 1971. Oslo, Norsk Polarinstitutt, 67-76.

Luckman, A. and T. Murray. 2005. Seasonal variations in velocity before retreat of Jacobshavn Isbræ, Greenland. Geophys. Res. Lett., 32(8), L08501. (10.1029/2005GL022519.)

MacDonald, T.R., J.G. Ferrigno, R.S. Williams, Jr and B.K. Lucchitta. 1989. Velocities of Antarctic outlet glaciers determined from sequential Landsat images. Antarct. J. US, 24(5), 105-106.

Meier, M.F. and 7 others. 2007. Glaciers dominate eustatic sealevel rise in the 21st century. Science, 317(5841), 1064-1067.

Nye, J.F. 1965. The flow of a glacier in a channel of rectangular elliptic or parabolic cross-section. J. Glaciol., 5(41), 661-690.

Paterson, W.S.B. 1994. The physics of glaciers. Third edition. Oxford, etc., Elsevier.

Reeh, N., H.H. Thomsen, A.K. Higgins and A. Weidick. 2001. Sea ice and the stability of north and northeast Greenland floating glaciers. Ann. Glaciol., 33, 474-480.

Sanderson, T.J.O. and C.S.M. Doake. 1979. Is vertical shear in an ice shelf negligible? J. Glaciol., 22(87), 285-292.

Scambos, T.A., M.J. Dutkiewicz, J.C. Wilson and R.A. Bindschadler. 1992. Application of image cross-correlation to the measurement of glacier velocity using satellite image data. Remote Sens. Environ., 42(3), 177-186.

Short, N.H. and A.L. Gray. 2005. Glacier dynamics in the Canadian High Arctic from RADARSAT-1 speckle tracking. Can. J. Remote Sens., 31(3), 225-239.

Trettin, H.P. 1989. The Arctic Islands. In Bally, A.W. and A.R. Palmer, eds. The geology of North America: an overview. Boulder, CO, Geological Society of America, 349-370.

Zwally, H.J., W. Abdalati, T. Herring, K. Larson, J. Saba and K. Steffen. 2002. Surface melt-induced acceleration of Greenland ice-sheet flow. Science, 297(5579), 218-222. 